nearly a hundred, listing their geographical and specialized knowledge. From war agencies 460 requests for information have been received since the Pearl Harbour disaster, and the Institution is also serving as an important source of technical and geographical information. Together with the National Research Council, the American Council of Learned Societies, and the Social Science Research Council, the Institution has participated in the setting up of the Ethnogeographic Board to provide a central clearing house for information to army and navy intelligence and other war agencies in geography, languages and social sciences. An index of published photographs taken by scientific workers of the Institution in all parts of the world is being compiled.

The Institution has also undertaken the publication of a handbook of the Indians of South America, under the editorship of Dr. J. H. Seward, of the Bureau of American Ethnology, as well as of a list of the insects of South and Central America. Volume 6 of the Annals of the Astrophysical Observatory, covering its operations from 1920 to 1939 , was published during the year and describes in detail the research on the variation of the sun's radiation. The Division of Radiation and Organisms, which was incorporated during the year as a branch of the Observa. tory, has continued its work on photosynthesis, plant growth and radiation, and the development of apparatus and methods. Experiments were continued on the factors that influence the changes in rates of respiration of plants, and work is in progress on the isolation and separation of two pigments that occur in dark-grown oat seedlings. The general appendix includes in the first place a statement "The 1914 Tests of the Langley "Aerodrome" ", by C. G. Abbot, which terminates the controversy between Dr. Orville Wright and the Institution. Among the original and unpublished papers in this appendix are those by J. A. Fleming on "The Sun and the Earth's Magnetic Field", E. P. Henderson and S. N. Perry on "Meteorites and their Metallic Constituents", and C. M. Packard on "Insect Enemies of our Cereal Crops".

\section{Copper Conductors for Overhead Lines}

IN a paper read by Messrs. G. W. Preston and H. G. Taylor in London on April 12 before the Institution of Electrical Engineers, the creep of copper conductors and their initial non-elastic extension are considered in relation to their effect on sags and their compensation by an increase in erection tension as an alternative to pre-stressing. Information is given on the annealing characteristics of harddrawn copper and copper-alloy conductors, with special reference to the effect of impurities in the metal, and maximum safe operating temperatures for such conductors are discussed, together with maximum permissible current loadings. Hollow copper conductors of various types for super-voltage lines are described, and the features of cadmiumcopper conductors are dealt with in comparison with other types of high-tensile overhead conductor. Steel-reinforced copper conductors receive special attention, particularly in regard to the protection from corrosion of the steel wires, and results of a long-time investigation are given in full, with conclusions and recommendations. Copper-clad steel wires, their characteristics and use as reinforcement in copper conductors are discussed. Details are given of developments in the application of compressed sleeve joints to copper and copper-alloy conductors, and suitable joints for cadmium-copper and steelcored copper conductors are deseribed and test results given.

\section{New Products from Celiulose}

ACCORDING to an annotation in the January issue of the Anglo-Swedish Review, the Swedish Cellulose Co. recently put on the market a wood-pulp product named 'Cellufix'; its manufacture requires the use of alkali, chlorine and alcohol, all of which are produced in Sweden. It is viscous, soluble in water at any temperature and so highly concentrated that a 3 per cent solution will yield a consistency equal to butter. It is odourless and tasteless, and its present main use is as wall-paper paste, as putty and for part of whitewash. 'Cellufix' is also used in textile mills as size and for other purposes. A specially purified quality of 'Cellufix' called 'Cellugel' is used in the food and chemical industries to give bulk to certain products and is also used as a substitute for glycerine.

\section{Planetaria of the World}

Mr. Roy K. Marshall continues his articles on this subject in the December and January issues of Sky and Telescope (see Nature, 153, 191 ; Feb. 12, 1944) with a very full description of the Fels Planetarium at the Franklin Institute, Philadelphia. $\mathrm{He}$ includes a few photographs of other planetaria also. The technical details of the instrument will prove interesting to many readers. The most complicated feature of the planetarium is the mechanism which reproduces the motions of the sun, moon and planets, and it is remarkable that comparatively few visitors make any inquiries about this. Five projectors are in the sun cage, and two of these are for a glow of light or aureole around the sun's image, simulating the strong scattering of light seen in the neighbourhood of the sun. One is for the zodiacal light, and a pair for the glow of the gegenschein. The precession of the equinoxes is reproduced in the planetarium by rotating the dumbbell portion of the instrument about an axis, and in 75 seconds it is possible to pass through the whole cycle of nearly 26,000 years. On certain occasions demonstrations of a highly dramatic nature have been presented-including a trip to the moon during which very realistic reproductions of lunar craters are produced. In the words of Dr. Philip Fox, describing the first Adler Planetarium, it is "not a trivial plaything, a mimic aping firmament, but the heavens portrayed in great dignity and splendour, dynamic, inspiring, in a way that dispels the mystery but retains the majesty".

\section{Rainfall in the Nile Basin}

A sxnopsis of rainfall statistics for the Nile Basin up to 1937 forms a valuable volume ("The Nile Basin", 6. By H. E. Hurst and R. P. Black. Physical Dept. Paper No. 43. Ministry of Public Works, Egypt. Cairo, 1943. 10s.). It includes figures from the Sudan, Uganda, Kenya, Tanganyika and the Belgian Congo. There are also figures, though admittedly incomplete, from Abyssinia. The stations are grouped by countries, and within each group are arranged by latitude from north to south. Statistics just outside the limits of the Nile basin are included. As a rule, stations with less than five years records are omitted. Figures from about four hundred stations make it possible to give a large-scale map of the total annual rainfall 
of the basin, and there are also graphs of the normal monthly rainfall and number of rainy days for selected stations in addition to the lists of these facts for each station where available. The volume concludes with a bibliography and a detailed index to stations.

\section{Public Health in Costa Rica}

The March issue of the Boletin de la Oficina Sanitaria Panamericana contains an article on this subject by the President, Dr. Rafael A. Calderon Guardia. The following details are of interest. The birth-rate for 1941 was 42.9 (slight increase) and the death-rate 17 per 1,000 . The death-rate for children under one year fell from 132.4 per 1,000 in 1940 to 123.5 in 1941 . The services for pre-school and school children have been extended, 11,074 children having been attended by medical men and 18,130 by dentists. During 1941 a section was formed to provide shoes for school children, one of the most important measures for protection of their health. For the first time a travelling exhibition for health education was started and circulated throughout the country. The Tuberculosis Division continued its work of systematic examination of the employees of the various divisions of the department of public health. Of 24,322 persons examined for venereal diseases, 4,242 were found to be infected and 1,305 were classified as doubtful. Soil sanitation was carried out intensively. The anti-malarial campaign was carried on according to the plans of the Rockefeller Foundation. New buildings have been constructed for health units in different parts of the country.

\section{Undulant Fever in Chile}

IN a recent article (Bol. Of. San. Panamericana, 22, 400 ; 1943) Enrique Onetto, director of the Diagnostic Laboratory of the Chile Bacteriological Institute, discusses the historical aspects and present state of undulant fever in Chile. The disease was first diagnosed in that country in 1931, when it was found near Santiago, and in 1940 a new focus was discovered in the northern part of the country. The commonest variety is Brucella melitensis, though Br. abortus has also been isolated in cattle. The infection is most prevalent in the southern part of Chile. Since 1936 the Huddleson reaction has been performed systematically on all the sera received for the Widal reaction. In 1936 also the Department of Public Health created a permanent commission for the study of brucellosis composed of medical men, bacteriologists and veterinarians.

\section{Rudolf Boehm (1844-1926)}

Prof. Rudolf BoEHM, a prominent pharmacologist, was born on May 19, 1844, at Nördlingen in Bavaria, the son of a medical man. He received his medical education at Munich, Würzburg and Leipzig, where he qualified in 1867. He first devoted himself to psychiatry, serving as assistant in the psychiatric clinic at Würzburg. Afterwards he took up the study of pharmacology at Leipzig and commenced his important studies on cardiac poisons. In 1871 he was appointed assistant at the Physiological Institute at Würzburg under A. Fick, and in the following year succeeded Schmiedeberg in the chair of pharmacology at Dorpat, eventually holding the corresponding chairs at Marburg and Leipzig. He died on August 16, 1926, in Upper Bavaria. Besides numerous pharmacological articles on veratrin, aconitin, arsenic, digitalis, and curare, and physiological investigations, especially on carbohydrate metabolism, he was the author of a "Lehrbuch der allgemeinen und speziellen Arzneiverordnungslehre" in 1884, the third edition appearing in 1903 .

\section{Announcements}

SrR Lewis Fermor, formerly director of the Geological Survey of India, has been awarded the P. N. Bose Memorial Medal for 1943 of the Royal Asiatic Society of Bengal, in recognition of his "conspicuously important researches on the Archæan Rocks of India".

Prof. C. M. Yonge, professor of zoology in the University of Bristol, has been appointed regius professor in the University of Glasgow, in succession to Prof. E. Hindle, who has become scientific director of the Zoological Society of London.

THE Rockefeller Foundation has made a grant of 15,000 rupees (about $£ 1,100$ ) to the National Institute of Sciences of India, to give assistance in the publication of scientific papers in Indian journals. This grant is similar in character to that which has been made by the Foundation to the Royal Society annually for some years, for assisting the publication of scientific papers in Great Britain.

THE following appointments in the Colonial Service have recently been made: $O$. J. Voelcker (senior botanist, Nigeria), seconded to Gold Coast for duty in connexion with cocoa diseases; D. Stevenson (senior assistant conservator of forests, Gold Coast), conservator of forests, Gold Coast; J. A. Wills (senior assistant conservator of forests, Gold Coast), conservator of forests, Gold Coast; C. M. Tattam (senior geologist, Nigeria), deputy director of geological surveys, Nigeria.

BY arrangement with the University of Cambridge, the Medical Research Council has established a Unit for Research in Applied Psychology at Cambridge. The Unit is located in the University Psychological Laboratory, the head of which is Prof. F. C. Bartlett. Dr. K. J. W. Craik has been appointed to the Council's staff as director of the Unit, and will have the collaboration or assistance of other workers there in the Council's service. The members of the Unit will undertake work elsewhere than at Cambridge when required, including investigations within the field of the Council's Industrial Health Research Board.

THE Institution of Chemical Engineers and the Institute of Physics announce a joint conference on "Instruments for the Automatic Controlling and Recording of Chemical and Other Processes". Provisional arrangements have been made for the conference to take place in London on September 22 and 23. The purpose of the conference is to promote the interchange of knowledge and experience between those employing automatic controllers and recorders in different fields and to encourage collaboration between physicists and chemical engineers. The conference will be open to all interested without charge. Further particulars will be sent, in August, to those sending a request for them to the Organizing Secretary, Joint Conference, c/o The Institution of Chemical Engineers, 56 Victoria Street, London, S.W.1. 